\title{
PERSEPSI KARYAWAN HOTEL TERHADAP MANFAAT SERTIFIKASI KOMPETENSI PARIWISATA BIDANG PERHOTELAN DI KOTA BANDUNG
}

\author{
Vindy Alvionita $^{(1)}$, A.H.G. Kusumah ${ }^{(2)}$, Sri Marhanah ${ }^{(3)}$ \\ (1)(2)(3) Program Studi Manajemen Resort \& Leisure \\ Universitas Pendidikan Indonesia \\ vindyalvionita53@gmail.com
}

\begin{abstract}
ABSTRAK
Sertifikasi Kompetensi Pariwisata merupakan kebijakan yang dibuat oleh pemerintah guna meningkatkan kualitas tenaga kerja di Indonesia, termasuk bidang perhotelan. Penelitianpenelitian sebelumnya menunjukkan bahwa pelaksanaan Sertifikasi Kompetensi Pariwisata belum terlaksana dengan baik dan maksimal walaupun tujuan dibuatnya sertifikasi yaitu untuk kebaikan tenaga kerja itu sendiri. Sehingga penelitian ini berfokus kepada persepsi karyawan hotel terhadap manfaat Sertifikasi Kompetensi Pariwisata. Tujuan penelitian ini yaitu untuk mengidentifikasi dan menganalisis persepsi karyawan hotel terhadap Sertifikasi Kompetensi Pariwisata. Metode kualitatif dipilih dengan menggunakan analisis isi dengan kerangka model Harold D. Lasswell. Narasumber terdiri dari 21 karyawan hotel dengan posisi dan tempat kerja yang berbeda. Hasil dari penelitian ini yaitu terdapat dua karakteristik karyawan hotel yaitu yang menyatakan Sertifikasi Kompetensi Pariwisata bermanfaat dan tidak bermanfaat berdasarkan level experience, scope dan linearity. Hasil penelitian lainnya yaitu dalam aspek jenjang karir, kinerja karyawan dan persaingan dengan tenaga kerja lain terbagi menjadi dua bagian yaitu karyawan hotel yang menyatakan Sertifikasi Kompetensi Pariwisata bermanfaat dan tidak bermanfaat berdasarkan persepsi-persepsi karyawan hotel.
\end{abstract}

Kata kunci: Sertifikasi Kompetensi Pariwisata, Persepsi Karyawan Hotel, Manfaat Sertifikasi Kompetensi Pariwisata.

\section{THE PERCEPTION OF HOTEL EMPLOYEES ON THE BENEFITS OF TOURISM COMPETENCY CERTIFICATION IN HOSPITALITY IN BANDUNG}

\begin{abstract}
Tourism Competency Certification is a policy made by the government to increase the qualification of Indonesian labors including hospitality. All the previous research showed that Tourism Competency Certification does not going well and reach the full potency according to the purpose, eventhough it was made for the good purpose for the labor itself. This research focusing on the perception of hotel employees on the benefits of Tourism Competency Certification in hospitality. The purpose of this research is to identifying and analyzing employees perception on the benefits of Tourism Competency Certification.. Qualitative method chosen for this research with content analysis from Harold D. Lasswell. Interviewees consist of 21 employees on different positions and work areas. The result of this research found two characteristics of employees that says Tourism Competency Certification beneficial for their worklife and not beneficial based on three levels, that is experience, scope and linearity. Another the result of this research is the aspect of career path, employees performance, and the competition with the other labors then divided into two perception, that
\end{abstract}


is hotel employees who certify Tourism Competency Certification is beneficial and not beneficial based on their perception.

Keywords: Tourism Competency Certification, The Perception of Hotel Employees, The Benefits of Tourism Competency Certification.

\section{PENDAHULUAN}

Sertifikasi adalah suatu prosedur yang melibatkan pihak ketiga sebagai pemberi jaminan tertulis bahwa suatu produk atau jasa telah memenuhi standar tertentu, berdasarkan audit yang dilaksanakan dengan prosedur yang disepakati. Sertifikasi Kompetensi Pariwisata merupakan prosedur yang menjadi kewajiban bagi seluruh karyawan hotel tak terkecuali, karena sertifikasi merupakan label yang menandakan kelayakan kemampuan dan skill yang dimiliki karyawan hotel dan menandakan sebagai Sumber Daya Manusia atau tenaga kerja yang berkualitas. Setiap karyawan hotel yang sudah tersertifikasi memiliki kesempatan yang besar untuk bersaing di industri perhotelan. Pemberlakuan Masyarakat Ekonomi ASEAN (MEA) menjadi tantangan tersendiri bagi Sumber Daya Manusia terlebih yang berkarir di industri perhotelan, karena persaingan yang dihadapi bukan hanya di negeri sendiri melainkan dengan semua negara-negara ASEAN. Sementara itu, peneliti menemukan masih kurangnya antusias karyawan-karyawan hotel untuk mengikuti Sertifikasi Kompetensi Pariwisata walaupun kebijakan tersebut bertujuan untuk kebaikan karyawan-karyawan hotel itu sendiri. Hal tersebut dapat ditemukan oleh peneliti selama peneliti melakukan penelitian ke beberapa hotel bintang 4 dan 5 di Kota Bandung, dimana terdapat karyawan-karyawan hotel yang bekerja di bagian operasional yang belum melakukan Sertifikasi Kompetensi bahkan terdapat juga beberapa karyawan hotel yang tidak mengetahui mengenai Sertifikasi Kompetensi Pariwisata.

Penelitian ini bertujuan untuk mengidentifikasi dan menganalisis persepsi karyawan hotel terhadap manfaat Sertifikasi Kompetensi Pariwisata, dimana kebijakan tersebut wajib dilaksanakan oleh seluruh karyawan hotel sesuai dengan Peraturan Pemerintah Republik Indonesia Nomor 52 Tahun 2012 tentang Sertifikasi Kompetensi dan Sertifikasi Usaha di Bidang Pariwisata. Penelitian ini diharapkan dapat menjadi salah satu saran dan masukan sebagai bahan evaluasi untuk pemerintah atau lembaga yang terkait untuk dapat memperbaiki halhal yang masih kurang dan harus dibenahi dalam pelaksanaan Sertifikasi Kompetensi Pariwisata berdasarkan persepsi yang diberikan oleh karyawan hotel. Secara gambaran umum, karyawan-karyawan hotel di Kota Bandung belum mentaati kebijakan dan Peraturan Pemerintah mengenai Sertifikasi Kompetensi Pariwisata karena banyak karyawan-karyawan hotel yang belum tersertifikasi. Hal tersebut menunjukkan bahwa antusias karyawan hotel di Kota Bandung dalam memenuhi peraturan sertifikasi kompetensi masih kurang. Seharusnya karyawan hotel dapat mentaati kebijakan tersebut karena sertifikasi kompetensi sangat berkaitan dengan jenjang karir, kinerja dan persaingan dengan tenaga kerja lain.

\section{LANDASAN TEORI}

\section{Persepsi}

Menurut Asrori (2009), persepsi adalah suatu proses yang dilalui oleh individu dalam menginterpretasikan, mengorganisasikan dan memberi makna terhadap rangsangan akan sesuatu hal yang berasal dari lingkungan dimana individu itu berada. Persepsi yang dikemukakan oleh seseorang dipengaruhi oleh faktor-faktor tertentu. Faktor-faktor yang mempengaruhi persepsi seseorang terdiri dari faktor internal 
dan faktor eksternal (Toha, 2003). Faktor internal meliputi perasaan, sikap dan kepribadian individu, prasangka, keinginan atau harapan, perhatian (fokus), proses belajar, keadaan fisik, gangguan kejiwaan, nilai dan kebutuhan juga minat, serta motivasi. Sedangkan faktor eksternal meliputi latar belakang keluarga, informasi yang diperoleh, pengetahuan dan kebutuhan sekitar, intensitas, ukuran, keberlawanan, pengulangan gerak, hal-hal baru dan familiar atau ketidak asingan suatu objek.

\section{Sertifikasi Kompetensi Pariwisata}

Menurut Undang-Undang No. 10 Tahun 2009 tentang Kepariwisataan, sertifikasi adalah proses pemberian sertifikat kepada usaha dan pekerja pariwisata untuk mendukung peningkatan mutu produk pariwisata, pelayanan, dan pengelolaan kepariwisataan. Sedangkan, kompetensi adalah seperangkat pengetahuan, keterampilan, dan perilaku yang harus dimiliki, dihayati, dan dikuasai oleh pekerja pariwisata untuk mengembangkan profesionalitas kerja. Proses pemberian sertifikasi dilakukan melalui uji kompetensi. Sertifikat Kompetensi di Bidang Pariwisata adalah bukti tertulis yang diterbitkan oleh lembaga sertifikasi profesi terlisensi yang menerangkan bahwa seseorang telah menguasai kompetensi kerja tertentu sesuai dengan Standard Kompetensi Kerja Nasional Indonesia (SKKNI) bidang pariwisata, standard internasional dan/atau standard khusus. Setiap tahun dilakukan survaillance pemegang sertifikat untuk memelihara kompetensi pemegang sertifikat. Manfaat Sertifikasi Kompetensi Pariwisata di bidang kepariwisataan bagi tenaga kerja yaitu sebagai berikut,

1. Membantu tenaga profesi meyakinkan kepada organisasi/industri/kliennya bahwa dirinya kompeten dalam bekerja atau menghasilkan produk atau jasa;

2. Membantu tenaga profesi dalam merencanakan karirnya;

3. Membantu tenaga profesi dalam memenuhi persyaratan regulasi;
4. Membantu pengakuan kompetensi lintas sektor dan lintas negara;

5. Membantu tenaga profesi dalam promosi profesinya di pasar tenaga kerja.

Berdasarkan Peraturan Pemerintah Republik Indonesia No. 52 Tahun 2012 tentang Sertifikasi Kompetensi dan Sertifikasi Usaha di Bidang Pariwisata Pasal 2, Sertifikasi Kompetensi di Bidang Pariwisata bertujuan untuk memberikan pengakuan terhadap kompetensi yang dimiliki tenaga kerja, dan meningkatkan kualitas dan daya saing tenaga kerja. Sementara itu, di dalam Pasal 7 tertulis bahwa pengembangan Sertifikasi Kompetensi di Bidang Pariwisata yaitu meliputi pengembangan standard kompetensi, pengembangan skema Sertifikasi Kompetensi di Bidang Pariwisata, penerapan Sertifikasi Kompetensi di Bidang Pariwisata, dan harmonisasi serta pengakuan Sertifikasi Kompetensi di Bidang Pariwisata.

\section{Kebijakan Sertifikasi Kompetensi Pariwisata}

Peraturan Pemerintah Republik Indonesia Nomor 52 Tahun 2012 tentang Sertifikasi Kompetensi dan Sertifikasi Usaha di Bidang Pariwisata mengatur mengenai Sertifikasi Kompetensi yang harus diikuti oleh seluruh tenaga kerja yang bekerja di bidang kepariwisataan, baik tenaga kerja dari dalam negeri maupun dari luar negeri. Di dalam Pasal 11 ayat (1) tertulis bahwa Sertifikasi Kompetensi di Bidang Pariwisata bersifat wajib. Sertifikat Kompetensi tersebut berlaku untuk 3 (tiga) tahun dan apabila sertifikat tersebut sudah melampaui masa berlakunya, maka tenaga kerja yang bersangkutan dapat memperpanjang sertifikat melalui Lembaga Sertifikasi Profesi Pariwisata.

Penilaian dalam Sertifikasi Kompetensi di Bidang Pariwisata dibedakan berdasarkan bidang pekerjaan masing-masing peserta sertifikasi. Sistem penilaian Sertifikasi Kompetensi dibagi menjadi dua yaitu klaster dan okupasi. Sistem penilaian dengan menggunakan klaster yaitu sistem penilaian secara lebih sederhana karena hanya 
memiliki jumlah unit penilaian yang sedikit dimana penilaiannya sesuai dengan gambaran umum job description masingmasing bidang pekerjaan. Sementara itu, sistem penilaian dengan menggunakan okupasi yaitu sistem penilaian secara lebih terperinci dan detail karena memiliki jumlah unit penilaian yang lebih kompleks dan lengkap.

\section{METODE}

Penelitian ini merupakan penelitian deskriptif dengan pendekatan kualitatif. Melalui metode kualitatif, peneliti dapat mendapatkan informasi lebih banyak dibandingkan jika peneliti menggunakan metode kuantitatif. Penelitian ini sangat membutuhkan banyak penjelasan dan penjabaran dari narasumber mengenai persepsi mereka terhadap manfaat Sertifikasi Kompetensi Pariwisata pada bidang perhotelan karena hasil dari penelitian ini mencakup persepsi, pandangan, dan pendapat yang diberikan oleh karyawan hotel. Metode kualitatif akan sangat membantu peneliti untuk menggali informasi sebanyak-banyaknya baik penjelasan, pendapat, saran, maupun masukan dari karyawan hotel, sehingga dari informasi tersebut peneliti dapat menarik hasil dan kesimpulan secara lebih rinci.

Penentuan subjek penelitian dilakukan dengan menggunakan teknik purposive sampling. Kriteria pengambilan sampel penelitian merupakan karyawan hotel baik yang sudah tersertifikasi maupun belum tersertifikasi, sudah menjadi karyawan tetap dan minimal sudah bekerja di industri perhotelan selama setahun. Teknik pengumpulan data dalam penelitian ini adalah observasi, wawancara mendalam (in depth interview) dan dokumentasi. Adapun instrumen wawancara yang digunakan dalam melakukan penelitian ini yaitu sebagai berikut,
Tabel 1. Instrumen Wawancara

\begin{tabular}{|c|c|c|}
\hline No & Variabel & Pertanyaan Wawancara \\
\hline \multirow[t]{4}{*}{1} & $\begin{array}{l}\text { Persepsi } \\
\text { Karyawan } \\
\text { Hotel }\end{array}$ & $\begin{array}{l}\text { 1. Seberapa penting Sertifikasi } \\
\text { Kompetensi Pariwisata bagi } \\
\text { Anda? }\end{array}$ \\
\hline & $\begin{array}{l}\text { Terhadap } \\
\text { Sertifikasi } \\
\text { Kompetensi } \\
\text { Pariwisata }\end{array}$ & $\begin{array}{ll}\text { 2. } & \text { Bagaimana peran dan } \\
\text { dampak Sertifikasi } \\
\text { Kompetensi Pariwisata dalam } \\
\text { menunjang karir Anda? }\end{array}$ \\
\hline & $\begin{array}{l}\text { Bidang } \\
\text { Perhotelan } \\
\text { di Kota } \\
\text { Bandung }\end{array}$ & $\begin{array}{l}\text { 3. Bagaimana peran Sertifikasi } \\
\text { Kompetensi Pariwisata dalam } \\
\text { menghadapi tantangan } \\
\text { dengan tenaga kerja asing? }\end{array}$ \\
\hline & & $\begin{array}{l}\text { 4. Bagaimana peran Sertifikasi } \\
\text { Kompetensi Pariwisata } \\
\text { terhadap kinerja karyawan di } \\
\text { hotel Anda bekerja? }\end{array}$ \\
\hline
\end{tabular}

Teknik analisis data dalam penelitian ini menggunakan analisis isi dengan kerangka model Harold D. Lasswell, yang di dalamnya menggunakan symbol coding dalam menganalisis data. Prosedur dasar pembuatan rancangan penelitian dan pelaksanaan studi analisis isi terdiri atas 6 (enam) tahapan langkah, yaitu:

1. Merumuskan pertanyaan penelitian dan hipotesisnya;

2. Melakukan sampling terhadap sumbersumber data yang telah dipilih;

3. Pembuatan kategori yang dipergunakan dalam analisis;

4. Pendataan suatu sampel dokumen yang telah dipilih dan melakukan pengkodean;

5. Pembuatan skala dan item berdasarkan kriteria tertentu untuk pengumpulan data;

6. Interpretasi atau penafsiran data yang diperoleh.

Di dalam tahapan proses penelitian dengan teknik analisis isi, terdapat 3 (tiga) langkah tahapan, diantaranya yaitu:

1. Penetapan desain atau model penelitian, dengan menetapkan berapa banyak media, analisis perbandingan atau korelasi, jumlah objek banyak atau sedikit, dan sebagainya.

2. Pencarian data pokok atau data primer, yaitu teks itu sendiri karena teks merupakan objek yang pokok dan pencarian dapat dilakukan dengan 
menggunakan lembar formulir pengamatan tertentu yang sengaja dibuat untuk keperluan pencarian data tersebut.

3. Pencarian pengetahuan kontekstual agar penelitian yang dilakukan tidak berada di ruang hampa, tetapi terlihat kait-mengait dengan faktor-faktor lain.

\section{HASIL DAN PEMBAHASAN}

Hasil temuan dari penelitian ini terdiri dari dua bagian, yaitu persepsi karyawan hotel terhadap manfaat Sertifikasi Kompetensi Pariwisata dan karakteristik karyawan hotel berdasarkan persepsi yang dikemukakan. Persepsi karyawan hotel terhadap manfaat Sertifikasi Kompetensi Pariwisata dan karakteristik karyawan hotel disajikan dalam penjabaran berikut ini

\section{Persepsi Karyawan Hotel Terhadap Manfaat Sertifikasi Kompetensi Pariwisata}

Berdasarkan hasil analisis data, Sertifikasi Kompetensi Pariwisata belum dirasakan oleh seluruh karyawan hotel. Sertifikasi Kompetensi Pariwisata belum dapat memberikan manfaat secara maksimal sesuai dengan tujuan pemerintah menciptakan kebijakan sertifikasi. Oleh karena itu, persepsi karyawan hotel terhadap manfaat Sertifikasi Kompetensi Pariwisata sangat diperlukan guna mengetahui hal-hal yang harus diperbaiki untuk menjadikan kebijakan sertifikasi tersebut lebih baik lagi di masa depan. Berikut ini merupakan persepsi karyawan hotel terhadap manfaat Sertifikasi Kompetensi Pariwisata bagi jenjang karir, kinerja karyawan dan persaingan dengan tenaga kerja lain.

\section{a. Jenjang Karir}

Karir adalah perkembangan para karyawan secara individu dalam jenjang jabatan/kepangkatan yang dapat dicapai selama masa kerja dalam suatu organisasi atau perusahaan (Soeprihanto, 2000). Manfaat terhadap jenjang karir yang dimaksud dalam penelitian ini menggambarkan bagaimana persepsi karyawan hotel mengenai manfaat Sertifikasi Kompetensi Pariwisata terhadap jenjang karir mereka. Berdasarkan hasil wawancara peneliti dengan 21 narasumber, terdapat 10 orang atau $47,62 \%$ yang berpendapat bahwa dengan mengikuti Sertifikasi Kompetensi Pariwisata dapat mempengaruhi dan bermanfaat bagi jenjang karir mereka dan 11 orang atau 52,38\% berpendapat sebaliknya. Sehingga, persepsi karyawan hotel yang mengatakan bahwa Sertifikasi Kompetensi Pariwisata tidak mempengaruhi jenjang karir lebih dominan. Persepsi karyawan hotel mengenai manfaat Sertifikasi Kompetensi Pariwisata terhadap jenjang karir terbagi menjadi dua, yaitu bermanfaat dan tidak bermanfaat. Persepsi yang menyatakan sertifikasi bermanfaat bagi jenjang karir dapat dilihat melalui potongan percakapan berikut,

"Yang pasti mengembangkan diri lah." (Narasumber 18)

Sertifikasi Kompetensi Pariwisata merupakan media untuk mengembangkan diri karena sertifikasi menjadi tolak ukur untuk setiap individu terhadap pencapaian yang sudah didapatkan, sehingga dapat mendorong setiap individu untuk mengembangkan diri menjadi lebih baik serta memperdalam wawasan mengenai standard dan prosedur secara umum. Persepsi karyawan tersebut sesuai dengan pernyataan yang dikemukakan oleh (Kandou, et al., 2016) bahwa keahlian seseorang dapat ditentukan dan dinilai berdasarkan seberapa baik seseorang dalam melaksanakan suatu kegiatan yang spesifik. Persepsi lainnya dapat dilihat melalui potongan percakapan berikut,

$$
\text { “...karena syarat supervisor }
$$
sebenernya harus ada sertifikasi, syarat supervisor, syarat manager." (Narasumber 13)

Sertifikat dari Sertifikasi Kompetensi Pariwisata dapat menjadi bahan pertimbangan pihak hotel karena sertifikat tersebut merupakan suatu pembuktian bahwa pemilik sertifikat memiliki skill yang sudah terukur dan 
layak untuk bekerja sesuai dengan bidang yang tertera di sertifikat, sehingga menjadi salah satu syarat untuk menaikkan level jabatan karyawan hotel tersebut. Persepsi lainnya dapat dilihat melalui potongan percakapan berikut,

"...bisa jadi nilai plus kalau mau apply kerja ke hotel-hotel gitu." (Narasumber 19)

Sertifikat tersebut diakui oleh negara sehingga dapat menjadi nilai plus saat pemilik sertifikat melamar pekerjaan. Persepsi karyawan hotel yang mengatakan bahwa Sertifikasi Kompetensi Pariwisata dapat mempengaruhi jenjang karir mereka sejalan dengan pernyataan yang dikemukakan oleh Hapsari (2016), yang menyatakan bahwa keuntungan bagi karyawan di tempat kerja yang telah bersertifikat meliputi jenjang karir dan promosi yang lebih baik, meningkatkan kesempatan untuk mengembangkan karir, dan pengakuan terhadap kompetensi yang dimiliki. Sementara itu, persepsi karyawan hotel yang menyatakan sertifikasi tidak bermanfaat bagi jenjang karir dapat dilihat melalui potongan percakapan berikut,

"...so far yang gue lihat enggak, karena orang-orang terdahulu yang pernah sertifikasi sebelumnya gitu yang tahun-tahun lalu juga gak dilihat dari situ tapi yang dilihat jam terbangnya, jam kerja gitu." (Narasumber 10)

Sertifikasi tidak berperan sebagai alat untuk mendapatkan pekerjaan ataupun menaikkan level jabatan karyawan hotel. Posisi yang mereka dapatkan saat ini dipengaruhi oleh beberapa faktor seperti kinerja, performance dan pengalaman kerja mereka, bukan karena sertifikasi. Hal tersebut diungkapkan oleh sebagian besar karyawan hotel baik yang sudah tersertifikasi maupun yang belum tersertifikasi. Oleh karena itu, kesuksesan jenjang karir seorang karyawan sangat berkesinambungan dengan kinerja karyawan itu sendiri, serta faktor lain seperti kemampuan dan motivasi.

Sertifikasi yang dilakukan di Indonesia dirasa masih kurang berpengaruh dalam meningkatkan jenjang karir mereka, terlebih lagi untuk berkarir di chain international hotel karena sudah memiliki program training khusus yang lebih detail dan berkala, serta lebih efektif dibandingkan dengan sistem pelaksanaan sertifikasi di Indonesia. Sertifikat yang didapatkan dari mengikuti training tersebut dipertimbangkan oleh semua chain international hotel baik di dalam negeri maupun di luar negeri, sehingga kesempatan untuk meningkatkan jenjang karir sangat terbuka lebar. Sesuai dengan pernyataan yang dikemukakan oleh Harlie (2011) bahwa karyawan merupakan suatu fokus inti dalam perkembangan suatu perusahaan, oleh karena itu karyawan harus memiliki karakteristik diantaranya yaitu keterampilan dan keahlian yang tinggi, wawasan dan pengetahuan yang luas, bakat dan potensi, kepribadian dan motif kerja, serta moral dan etos kerja yang tinggi. Namun Sertifikasi Kompetensi Pariwisata dapat menjadi nilai plus sebagai pembuktian legalitas dan kelayakan kerja.

\section{b. Kinerja Karyawan}

Kinerja adalah suatu hasil kerja yang dicapai seseorang dalam melaksanakan tugas-tugas yang dibebankan kepadanya yang didasarkan atas kecakapan, inisiatif, pengalaman, dan kesungguhan, serta waktu (Hasibuan, 2014). Karyawan adalah tenaga kerja manusia jasmaniah maupun rohaniah yang senantiasa dibutuhkan dan menjadi salah satu modal pokok dalam usaha kerjasama untuk mencapai tujuan tertentu. Di dalam industri pariwisata khususnya perhotelan, kinerja karyawan dapat dinilai baik jika pelaksanaan operational di hotel tersebut berjalan dengan baik. Oleh karena itu, hotel sangat membutuhkan karyawankaryawan yang sigap, cekatan, dan 
memiliki skill atau kemampuan yang baik dalam handling complaint karena yang dihadapi adalah banyak orang dengan karakteristik yang berbeda-beda.

Sertifikasi Kompetensi Pariwisata merupakan salah satu alat pengukur skill atau kemampuan karyawan hotel pada bidangnya masing-masing. Peneliti melakukan penelitian mengenai manfaat Sertifikasi Kompetensi Pariwisata terhadap kinerja karyawan. Manfaat terhadap kinerja karyawan yang dimaksud dalam penelitian ini menggambarkan bagaimana persepsi karyawan hotel mengenai manfaat Sertifikasi Kompetensi Pariwisata terhadap kinerja karyawan, sertifikasi memberikan pengaruh yang signifikan atau tidak terhadap peningkatan kinerja karyawan.

Berdasarkan hasil wawancara dengan 21 narasumber, 8 orang atau $38,10 \%$ mengatakan Sertifikasi Kompetensi Pariwisata berpengaruh kepada kinerja karyawan menjadi lebih baik dan 13 orang atau $61,90 \%$ yang memiliki persepsi sebaliknya. Secara garis besar, persepsi karyawan hotel mengenai manfaat Sertifikasi Kompetensi Pariwisata terhadap kinerja karyawan terbagi menjadi dua, yaitu bermanfaat dan tidak bermanfaat. Persepsi karyawan hotel yang menyatakan sertifikasi bermanfaat bagi kinerja karyawan dapat dilihat melalui potongan percakapan berikut,

"Bedanya lebih berpengalaman sih yang sertifikasi, gitu." (Narasumber 9)

Sertifikasi akan memberikan pengalaman tambahan untuk karyawan hotel karena di dalam pelaksanaannya sertifikasi akan mengulas mengenai basic prosedur, standard pelayanan, dan job description yang harus dikuasai oleh setiap karyawan hotel di bidang yang sudah dipilih. Melalui proses tersebut, maka tenaga kerja yang sudah tersertifikasi akan lebih banyak membantu dalam pekerjaan operational.
Persepsi lainnya dapat dilihat melalui potongan percakapan berikut,

"Ya berpengaruh sih sertifikasi dalam meningkatkan kualitas SDM, soalnya kan kemaren juga di Padma hmm yang belum punya sertifikat ujikom di ujikom-in di Badan LSP kalau gak salah, gitu. Jadi kan memang harus punya skill dong sesuai dengan bidangnya. Jadi ya penting peran sertifikasinya." (Narasumber 21)

Sertifikasi Kompetensi Pariwisata merupakan salah satu kebijakan yang dibuat oleh pemerintah untuk meningkatkan kualitas SDM dan sertifikasi merupakan suatu proses untuk menyetarakan prosedur dan standard pelayanan yang diberikan oleh karyawan di seluruh hotel. Sehingga melalui sertifikasi, karyawan hotel akan mengalami peningkatan kualitas kerja dan dapat memberi kinerja yang lebih baik untuk hotel tempat bekerjanya. Hal tersebut sesuai dengan pernyataan yang dikemukakan oleh Hapsari (2016), bahwa keuntungan dari adanya sertifikasi bagi perusahaan atau tempat kerja yaitu mencakup produktivitas meningkat, mengurangi kesalahan kerja, komitmen terhadap kualitas, memudahkan dalam penerimaan karyawan, dan mempunyai karyawan yang berdaya saing, terampil dan termotivasi. Sementara itu, persepsi karyawan hotel yang menyatakan sertifikasi tidak bermanfaat bagi kinerja karyawan dapat dilihat melalui potongan percakapan berikut,

"Sebenarnya kalau untuk pelaksanaan kerja orang bersertifikat atau enggak balik lagi ke orangnya ya, maksudnya orangnya itu disiplin apa enggak, gitu, terus males-malesan apa enggak. Pada saat orang itu belum tersertifikat pun kalau emang kinerja dia udah baik ya dia bakalan stabil di baik, gitu. Tapi even misalkan dia sudah bersertifikat tapi pada dasarnya dia kaya sering ngaret lah apa segala macem ya habitnya akan tetap kebawa, jadi gak menjamin orang yang bersertifikat akan 
lebih unggul gitu, gak menjamin." (Narasumber 10)

Persepsi tersebut menyatakan bahwa baik atau buruknya kinerja karyawan hotel tergantung dari individu karyawan itu sendiri. Karyawan hotel yang sudah tersertifikasi tidak menjamin akan memberikan pelayanan yang lebih baik dibandingkan karyawan hotel yang belum tersertifikasi, karena karyawan hotel yang sudah tersertifikasi belum tentu mengimplementasikan ilmu yang didapatkan dari sertifikasi yang sudah diikuti. Kinerja karyawan hotel dapat dipengaruhi oleh banyak faktor, seperti pengalaman kerja, habit karyawan, etos kerja, dan company's behavior yang dimiliki. Selain itu, penilaian kinerja diukur dengan beberapa indikator seperti tanggung jawab dan disiplin. Hal tersebut diperkuat dengan pernyataan yang dikemukakan menurut Prawirosentono (2008), bahwa kinerja dapat dinilai atau diukur dengan beberapa indikator yaitu efektifitas, tanggung jawab, disiplin, dan inisiatif. Kinerja karyawan juga lebih dipengaruhi oleh training-training internal yang dilakukan pihak hotel. Sehingga, Sertifikasi Kompetensi Pariwisata bukan merupakan faktor utama untuk meningkatkan kualitas kinerja karyawan.

\section{c. Persaingan dengan Tenaga Kerja Lain}

Persaingan atau yang dikenal dengan istilah kompetisi merupakan bagian dari konflik, dimana konflik dapat terjadi karena perjuangan individu untuk memperoleh hal-hal yang langka, seperti nilai, status, kekuasaan, otoritas dan lainnya, dimana tujuan dari mereka yang berkonflik itu tidak hanya untuk memperoleh keuntungan, tetapi juga menundukkan saingannya (Anoraga, 2001). Di dalam penelitian ini, terdapat dua persepsi karyawan hotel mengenai manfaat Sertifikasi Kompetensi Pariwisata dalam menghadapi persaingan dengan tenaga kerja lain, yaitu yang menyatakan bermanfaat dan tidak bermanfaat. Manfaat bagi persaingan dengan tenaga kerja lain yang dimaksud dalam penelitian ini menggambarkan bagaimana persepsi karyawan hotel mengenai manfaat Sertifikasi Kompetensi Pariwisata terhadap persaingan dengan tenaga kerja lain.

Berdasarkan hasil wawancara peneliti dengan 21 narasumber, 10 atau 47,62\% menyatakan bahwa sertifikasi bermanfaat bagi persaingan dengan tenaga kerja lain dan 11 orang atau $52,38 \%$ yang menyatakan sebaliknya. Secara garis besar, persepsi karyawan hotel mengenai manfaat Sertifikasi Kompetensi Pariwisata terhadap persaingan dengan tenaga kerja lain terbagi menjadi dua, yaitu bermanfaat dan tidak bermanfaat. Persepsi karyawan hotel yang menyatakan sertifikasi bermanfaat bagi persaingan dengan tenaga kerja lain dapat dilihat melalui potongan percakapan berikut,

"Kalau untuk persaingannya bisa dibilang kalau udah tersertifikasi nah kita dianggapnya satu level sama itu. Dibandingkan dengan kita gak punya, gak mungkin tenaga asing itu tiba-tiba masuk, pasti mereka juga punya standar." (Narasumber 15)

Persepsi karyawan hotel yang mengatakan bahwa Sertifikasi Kompetensi Pariwisata dapat membantu mereka dalam menghadapi persaingan dengan tenaga kerja lain termasuk tenaga kerja asing yaitu sertifikat yang mereka peroleh dapat berperan sebagai daya jual untuk melamar kerja karena sertifikat tersebut sudah diakui oleh negara, sehingga secara garis besar maka skill yang mereka miliki juga sudah diakui oleh negara. Persepsi lainnya dapat dilihat melalui potongan percakapan berikut,

"Jadi kalau misalkan pengaruhnya apa ya jadi lebih percaya diri lah, lebih percaya diri jadi lebih aman aja, bahwa kita gak cuman skill-nya doang tapi secara administrasi juga kita udah layak gitu." (Narasumber 15)

Sertifikasi memberikan peningkatan 
kepercayaan diri karena status sertifikat yang mereka punya sudah diakui oleh negara dan sangat berperan menjadi supporting document atau nilai plus saat karyawan hotel melamar pekerjaan ke hotel. Persepsi karyawan hotel bahwa Sertifikasi Kompetensi Pariwisata dapat meningkatkan kepercayaan diri tersebut sejalan dengan pernyataan yang dikemukakan oleh Hapsari (2016) yang mengatakan bahwa bagi pencari kerja yang mempunyai sertifikat kompetensi meliputi kredibilitas dan kepercayaan dirinya akan meningkat, mempunyai bukti bahwa kompetensi yang dimiliki telah diakui, bertambahnya nilai jual dalam rekrutmen tenaga kerja, kesempatan berkarir yang lebih besar, dan mempunyai parameter yang jelas akan adanya keahlian dan pengetahuan yang dimiliki. Sementara itu, persepsi karyawan hotel yang menyatakan sertifikasi tidak bermanfaat bagi persaingan dengan tenaga kerja lain dapat dilihat melalui potongan percakapan berikut,

“...so far belum kelihatan ya, karena memang itu tadi yang gue bilang, sebenarnya sertifikasi itu masih belum terlalu ampuh untuk kita misal "nih pak saya punya sertifikasi ini" terus jaminan lu akan lebih." (Narasumber 10)

Melalui potongan percakapan wawancara tersebut, secara terperinci terdapat faktor-faktor tertentu yang menjadi pertimbangan pihak hotel dalam memilih tenaga kerja sebagai karyawan hotel dan/atau meningkatkan level jabatan karyawan hotel. Faktor-faktor yang mempengaruhi persaingan dengan tenaga kerja lain yaitu berdasarkan kualitas dari tenaga kerja itu sendiri, karena tenaga kerja yang sudah tersertifikasi belum tentu merupakan tenaga kerja yang berkualitas, walaupun tujuan diadakannya sertifikasi untuk meningkatkan kualias SDM. Kualitas tenaga kerja dapat dilihat melalui basic yang dimiliki baik hardskill maupun softskill. Basic tersebut merupakan faktor terpenting yang dipertimbangkan dalam mendapatkan pekerjaan. Faktor lain yang juga penting dalam mempengaruhi persaingan dengan tenaga kerja lain adalah performance dan pengalaman kerja, karena semakin banyak pengalaman kerja yang dimiliki baik dari segi tempat maupun lamanya bekerja, maka skill dan kemampuan yang dimiliki juga semakin banyak dan hal tersebut dapat mempengaruhi performance. Persepsi lainnya dapat dilihat melalui potongan percakapan berikut,

"Karena kalau misalkan di luar negeri, aku rasa sertifikasi yang kita dapet dari Indonesia ini itu gak akan $\mathrm{hmm}$ berpengaruh banyak karena hmm untuk hotel-hotel di luar negeri, chain international, itu seperti yang aku bilang, mereka udah punya training-nya sendiri dan mereka akan memberikan sertifikasinya sendiri, gitu." (Narasumber 16)

Di sisi lain dari ketiga faktor yang sudah dijelaskan tersebut, faktor lain yang menjadikan Sertifikasi Kompetensi Pariwisata masih belum menjadi senjata yang ampuh untuk menghadapi persaingan dengan tenaga kerja lain. Berdasarkan pernyataan yang dikemukakan oleh Hapsari (2016), bahwa saat ini banyak sertifikasi dibangun hanya berdasarkan niat baik, tetapi belum dibangun dengan kesisteman dan kompeten yang mampu ditelusur. Sehingga, untuk memastikan dan memelihara kompetensi diperlukan sistem sertifikasi yang kredibel. Hal tersebut menjadikan Sertifikasi Kompetensi Pariwisata belum dapat memberikan peran yang signifikan dalam mempengaruhi persaingan antar tenaga kerja. Faktor lainnya yaitu karena hotelhotel chain international memiliki sistem training tersendiri bagi para karyawannya. Training tersebut dilakukan secara berkala sehingga kemampuan, knowledge dan skill karyawan-karyawan 
hotelnya dapat termonitor dan selalu mendapatkan pembaharuan. Sertifikat dari training tersebut dapat berlaku untuk semua chain international hotel baik di dalam maupun di luar negeri. Selain itu dalam menghadapi persaingan dengan tenaga kerja lain, karyawan hotel juga tidak hanya dapat mengandalkan sertifikat, melainkan harus memiliki mental dan kepercayaan diri yang kuat.

Sertifikasi Kompetensi Pariwisata belum dapat menjadi suatu senjata yang berperan secara signifikan dalam menghadapi persaingan tenaga kerja, namun sertifikasi mampu memberikan perlindungan kepada tenaga kerja Indonesia di dalam industri pariwisata. Hal tersebut sesuai dengan pernyataan yang dikemukakan oleh Hapsari (2016) yang menyatakan bahwa sertifikasi mempunyai fungsi ganda, yakni memberikan proteksi kepada tenaga kerja pariwisata dalam negeri dari serangan tenaga kerja asing dan sekaligus memberikan dan meningkatkan rekognisi dalam persaingan kompetensi global. Satu hal yang menjadi pertimbangan adalah bahwa Sertifikasi Kompetensi Pariwisata sebagai modal perangkat infrastruktur SDM sangat mutlak diperlukan dalam menghadapi persaingan di pasar global.

\section{Rekapitulasi Persepsi Karyawan Hotel Terhadap Manfaat Sertifikasi Kompetensi Pariwisata}

Persepsi karyawan hotel terhadap manfaat Sertifikasi Kompetensi Pariwisata terbagi menjadi dua di dalam setiap aspek yaitu bermanfaat dan tidak bermanfaat, baik bagi jenjang karir, kinerja karyawan dan persaingan dengan tenaga kerja lain. Berikut ini merupakan rekapitulasi hasil penelitian berdasarkan persepsi karyawan hotel di setiap aspek.

Tabel 2. Rekapitulasi Persepsi Karyawan Hotel Terhadap Manfaat Sertifikasi Kompetensi Pariwisata

\begin{tabular}{|c|c|c|c|c|c|}
\hline \multicolumn{2}{|c|}{ Jenjang Karir } & \multicolumn{2}{|c|}{ Kinerja Karyawan } & \multicolumn{2}{|c|}{$\begin{array}{c}\text { Persaingan dengan Tenaga Kerja } \\
\text { lain }\end{array}$} \\
\hline Bermanfaat & $\begin{array}{c}\text { Tidak } \\
\text { Bermanfaat }\end{array}$ & Bermanfaat & Tidak Bermanfaat & Bermanfaat & Tidak Bermanfaat \\
\hline $\begin{array}{l}\text { Media } \\
\text { mengembangkan } \\
\text { diri }\end{array}$ & \multirow[t]{2}{*}{$\begin{array}{l}\text { Tidak } \\
\text { menjadi nilai } \\
\text { plus }\end{array}$} & $\begin{array}{l}\text { Memiliki } \\
\text { knowledge } \\
\text { lebih luas }\end{array}$ & \multirow{2}{*}{$\begin{array}{l}\text { Kinerja karyawan tidak } \\
\text { didasarkan oleh status } \\
\text { sertifikasi, melainkan } \\
\text { pengalaman kerja, } \\
\text { habit karyawan, etos } \\
\text { kerja, dan company's } \\
\text { behavior }\end{array}$} & $\begin{array}{l}\text { Sebagai daya } \\
\text { jual }\end{array}$ & \multirow{3}{*}{$\begin{array}{l}\text { Hal-hal yang } \\
\text { mempengaruhi } \\
\text { persaingan dengan } \\
\text { tenaga kerja lain } \\
\text { yaitu basic baik } \\
\text { hardskill maupun } \\
\text { softskill, } \\
\text { performance, dan } \\
\text { pengalaman kerja }\end{array}$} \\
\hline $\begin{array}{l}\text { Sebagai bahan } \\
\text { pertimbangan } \\
\text { pihak hotel }\end{array}$ & & $\begin{array}{l}\text { Me-refresh } \\
\text { knowledge } \\
\text { mengenai } \\
\text { prosedur dan } \\
\text { standar } \\
\text { pelayanan } \\
\text { hotel }\end{array}$ & & $\begin{array}{l}\text { Meningkatkan } \\
\text { kepercayaan } \\
\text { diri }\end{array}$ & \\
\hline $\begin{array}{l}\text { Salah satu syarat } \\
\text { untuk menaikkan } \\
\text { level jabatan }\end{array}$ & \multirow{3}{*}{$\begin{array}{l}\text { Tidak } \\
\text { membantu } \\
\text { menaikkan } \\
\text { level jabatan }\end{array}$} & $\begin{array}{l}\text { Lebih } \\
\text { berpengalaman }\end{array}$ & $\begin{array}{l}\text { Setiap hotel memiliki } \\
\text { prosedur dan standard } \\
\text { operational yang }\end{array}$ & \multirow{3}{*}{$\begin{array}{l}\text { Menjadi satu } \\
\text { level dengan } \\
\text { tenaga kerja } \\
\text { asing dan } \\
\text { mendapat } \\
\text { peluang yang } \\
\text { sama }\end{array}$} & \\
\hline Sebagai nilai plus & & $\begin{array}{l}\text { Memudahkan } \\
\text { operational }\end{array}$ & berbeda-beda & & \multirow{2}{*}{$\begin{array}{l}\text { Adanya sistem } \\
\text { training tersendiri } \\
\text { pada chain } \\
\text { international hotel }\end{array}$} \\
\hline Diakui negara & & $\begin{array}{l}\text { Meningkatkan } \\
\text { kualitas SDM }\end{array}$ & $\begin{array}{l}\text { Ada training secara } \\
\text { berkala oleh pihak } \\
\text { hotel yang lebih detail }\end{array}$ & & \\
\hline
\end{tabular}

Sumber: Hasil Olah Data, 2018

Berdasarkan tabel tersebut, persepsi karyawan hotel terhadap manfaat Sertifikasi Kompetensi Pariwisata bagi jenjang karir, kinerja karyawan dan persaingan dengan tenaga kerja lain belum terealisasi dengan baik. Hal tersebut dibuktikan dengan 
dominannya karyawan hotel yang mengemukakan Sertifikasi Kompetensi Pariwisata tidak bermanfaat terhadap ketiga aspek tersebut. Persepsi-persepsi yang mendasari bermanfaat atau tidak bermanfaatnya Sertifikasi Kompetensi Pariwisata dapat dilihat melalui tabel rekapitulasi tersebut.

Besar atau kecilnya manfaat yang diperoleh merupakan salah satu indikator untuk menyatakan penting atau tidaknya suatu hal. Berdasarkan wawancara yang sudah dilakukan oleh peneliti mengenai persepsi karyawan hotel terhadap manfaat Sertifikasi Kompetensi Pariwisata, ditemukan bahwa sertifikasi dapat dikatakan penting jika memberikan manfaat yang signifikan. Di dalam penelitian ini, karyawan hotel mengemukakan bahwa Sertifikasi Kompetensi Pariwisata adalah hal yang penting namun tidak serta merta memberikan manfaat yang signifikan baik terhadap jenjang karir, kinerja karyawan dan persaingan dengan tenaga kerja lain. Hal tersebut dibuktikan dengan terdapat 12 dari 21 karyawan hotel atau 57,14\% yang mengatakan sertifikasi penting, artinya karyawan hotel yang mengatakan sertifikasi penting lebih dominan. Secara umum, karyawan hotel menyatakan sertifikasi penting karena sertifikat yang diperoleh dapat menjadi penunjang dalam mencari pekerjaan di awal karir dan merupakan suatu dokumen bukti pengakuan oleh negara. Sedangkan persepsi karyawan hotel terhadap jenjang karir, kinerja karyawan maupun persaingan dengan tenaga kerja lain lebih dominan mengatakan bahwa Sertifikasi Kompetensi Pariwisata tidak memberikan manfaat yang signifikan sehingga pelaksanaan sertifikasi kompetensi dirasa tidak diperlukan. Hal tersebut dapat dilihat melalui persentase persepsi karyawan hotel yang menyatakan Sertifikasi Kompetensi Pariwisata tidak bermanfaat bagi jenjang karir yaitu 52,38\%, kinerja karyawan yaitu $61,90 \%$, dan persaingan dengan tenaga kerja lain yaitu $52,38 \%$.

\section{a. Karakteristik Karyawan Hotel}

Menurut Rahman (2013), karakteristik individu adalah ciri khas yang menunjukkan perbedaan seseorang tentang motivasi, inisiatif, kemampuan untuk tetap tegar menghadapi tugas sampai tuntas atau memecahkan masalah atau bagaimana menyesuaikan perubahan yang terkait erat dengan lingkungan yang mempengaruhi kinerja individu. Karakteristik individu mencakup sifatsifat berupa kemampuan dan keterampilan; latar belakang keluarga, sosial, dan pengalaman; umur, bangsa, jenis kelamin dan lainnya yang mencerminkan sifat demografis tertentu; serta karakteristik psikologis yang terdiri dari persepsi, sikap, kepribadian, belajar, dan motivasi (Winardi, 2004).

Berdasarkan persepsi yang dikemukakan oleh karyawan hotel, terdapat tiga level yang menjadi cakupan dari karakteristik karyawan hotel. Level yang dimaksud adalah suatu kategori yang menggambarkan nilai yang dimiliki oleh setiap individu karyawan hotel secara keseluruhan, bukan hanya skill dan kemampuan saja. Level tersebut terbagi menjadi tiga yaitu experience, scope dan linearity. Karakteristik karyawan hotel berdasarkan ketiga level tersebut disajikan dalam tabel berikut

Tabel 3. Karakteristik Karyawan Hotel

\begin{tabular}{|c|c|c|}
\hline \multirow{2}{*}{ Level } & \multicolumn{2}{|c|}{ Persepsi Terhadap Manfaat } \\
\hline & Bermanfaat & Tidak Bermanfaat \\
\hline Experience & $\begin{array}{l}\text { - } \quad \text { Pengalaman kerja sedikit } \\
\text { - } \quad \text { Belum berada di posisi level menengah atau tinggi }\end{array}$ & $\begin{array}{l}\text { - } \quad \text { Pengalaman kerja banyak } \\
\text { - } \quad \text { Berada di posisi level menengah atau tinggi }\end{array}$ \\
\hline Scope & Bekerja di hotel local & Bekerja di hotel chain international \\
\hline Linearity & $\begin{array}{l}\text { Background pendidikan bukan industri pariwisata atau } \\
\text { hospitality }\end{array}$ & $\begin{array}{l}\text { Background pendidikan dari industri pariwisata } \\
\text { atau hospitality }\end{array}$ \\
\hline
\end{tabular}

Sumber: Hasil Olah Data, 2018 
Experience yaitu pengalaman kerja karyawan hotel berdasarkan persepsi yang dikemukakannya karena banyaknya pengalaman kerja dapat mempengaruhi kualitas karyawan hotel. Hal tersebut sejalan dengan pernyataan Abriani (2004), bahwa semakin luas pengalaman kerja seseorang, semakin terampil melakukan pekerjaan dan semakin sempurna pola berpikir dan sikap dalam bertindak untuk mencapai tujuan yang telah ditetapkan. Terdapat beberapa hal untuk menentukan berpengalaman tidaknya seorang karyawan yang sekaligus sebagai indikator pengalaman kerja menurut Foster (2001) yaitu lama waktu atau masa kerja, tingkat pengetahuan dan keterampilan yang dimiliki, serta penguasaan terhadap pekerjaan dan peralatan. Di dalam level experience, karyawan hotel yang menyatakan Sertifikasi Kompetensi Pariwisata bermanfaat yaitu karyawan hotel yang memiliki pengalaman kerja sedikit dan belum berada di posisi level menengah atau tinggi. Sedangkan karyawan hotel yang menyatakan tidak bermanfaat yaitu karyawan hotel yang memiliki pengalaman kerja banyak dan berada di posisi level menengah atau tinggi. Pengalaman kerja berbicara mengenai seberapa lama dan banyaknya posisi yang sudah dilalui oleh karyawan hotel (track record). Sedangkan posisi level menengah atau tinggi merupakan suatu tolak ukur bagi karyawan hotel mengenai kemampuan dan skill yang dimiliki karena karyawan di level menengah atau tinggi dipastikan sudah memiliki kapabilitas dalam melakukan berbagai pekerjaan besar.

Scope yaitu lingkup kerja karyawan hotel. Lingkup kerja yang dimaksud adalah cakupan tempat kerja karyawan hotel, baik hotel lokal maupun hotel internasional. Lingkup kerja dapat mempengaruhi karakteristik karyawan hotel karena di dalam lingkup kerja terdapat beberapa unsur seperti lingkungan kerja, prosedur kerja, standar operasional, dan kebijakan perusahaan atau hotel. Karakteristik karyawan hotel yang menyatakan Sertifikasi Kompetensi bermanfaat yaitu karyawan hotel yang bekerja di hotel lokal. Sedangkan karyawan hotel yang menyatakan tidak bermanfaat yaitu karyawan hotel yang bekerja di hotel chain international. Hotel chain international memiliki program training yang lebih detail dan dilakukan secara berkala sehingga skill dan kemampuan karyawannya dapat terus termonitor. Sedangkan hotel lokal pada umumnya tidak memiliki program training tersebut sehingga sertifikasi merupakan suatu media untuk mengembangkan diri.

Linearity yaitu relevansi atau ketepatan antara background pendidikan dengan bidang pekerjaan. Menurut Muhson, et al., (2009), relevansi adalah kesesuaian antara kemampuan atau skill yang diperoleh melalui jenjang pendidikan dengan kebutuhan pekerjaan. Ketepatan background pendidikan dengan bidang pekerjaan yang dijalani dapat mempengaruhi persepsi yang dimiliki oleh karyawan hotel, sehingga terciptanya karakteristik yang berbeda dengan karyawan hotel yang bekerja sesuai dengan background pendidikan yang ditempuh. Karakteristik karyawan hotel yang menyatakan Sertifikasi Kompetensi Pariwisata bermanfaat yaitu karyawan hotel yang memiliki background pendidikan bukan dari industri pariwisata atau hospitality. Sedangkan karyawan hotel yang menyatakan tidak bermanfaat yaitu karyawan hotel yang memiliki background pendidikan berasal dari pendidikan industri pariwisata atau hospitality.

\section{KESIMPULAN}

Persepsi karyawan hotel terhadap manfaat Sertifikasi Kompetensi Pariwisata berdasarkan hasil wawancara kepada seluruh narasumber terbagi menjadi dua kelompok 
Vindy Alvionita, A.H.G. Kusumah dan Sri Marhanah: Persepsi Karyawan Hotel Terhadap Manfaat Sertifikasi Kompetensi Pariwisata Bidang Perhotelan di Kota Bandung

karyawan yang menyatakan Sertifikasi Kompetensi Pariwisata dapat bermanfaat dan tidak bermanfaat bagi jenjang karir, kinerja karyawan, dan persaingan dengan tenaga kerja lain. Berdasarkan hasil dan temuan pada penelitian, karyawan hotel dominan memiliki persepsi bahwa Sertifikasi Kompetensi Pariwisata tidak memberikan manfaat yang signifikan bagi jenjang karir, kinerja karyawan dan persaingan dengan tenaga kerja lain.

Karakteristik karyawan hotel dapat ditemukan berdasarkan cakupan tiga level yang berbeda, yaitu experience, scope, dan linearity. Experience merupakan pengalaman kerja karyawan hotel baik berupa lamanya bekerja maupun posisi apa saja yang pernah dilalui. Scope merupakan lingkup kerja berupa cakupan tempat kerja karyawan hotel. Linearity merupakan relevansi atau ketepatan antara background pendidikan dengan bidang pekerjaan. Karakteristik karyawan hotel di dalam level experience didasarkan oleh banyak atau tidaknya pengalaman kerja dan posisi level jabatan, level scope didasarkan oleh tempat bekerja karyawan hotel, meliputi hotel lokal dan chain international hotel, dan level linearity didasarkan oleh tingkat ketepatan antara background pendidikan karyawan hotel dengan bidang pekerjaan.

\section{DAFTAR PUSTAKA}

Abriani, Puspaningsih. (2004). FaktorFaktor yang Berpengaruh Terhadap Kepuasan Kerja dan Kinerja Manajer Perusahaan Manufaktur. Jakarta: Jurnal Akuntansi dan Auditing Indonesia.

Anoraga, Panji. (2001). Psikologi Kerja. Jakarta: Rineka Cipta.

Asrori, Mohammad. (2009). Psikologi Pembelajaran. Bandung: CV. Wacana Prima.

Foster, Bill. (2001). Pembinaan untuk Peningkatan Kinerja Karyawan. Jakarta: PPM.

Hapsari, Melati Indri. (2016). Pengkajian Program Kursus dan Pelatihan
Terkait dengan Jenis Keterampilan, Sertifikasi dan Penempatan Lulusan. Semarang: Universitas Negeri Semarang.

Hasibuan, Malayu S. P. (2014). Manajemen Sumber Daya Manusia. Jakarta: Bumi Aksara.

Harlie, M. (2011). Pengaruh Disiplin Kerja, Motivasi dan Pengembangan Karier Terhadap Kinerja Pegawai Negeri Sipil pada Pemerintah Kabupaten Tabalong di Tanjung Kalimantan Selatan. Kalimantan Selatan: STIA Tabalong.

Kandou, Yunita Lidya, Victor P. K. Lengkong, dan Greis Sendow. (2016). Pengaruh Knowledge Management, Skill dan Attitude Terhadap Kinerja Karyawan (Studi Pada PT. Bank Sulutgo Kantor Pusat di Manado). Manado: Universitas Sam Ratulangi.

Muhson, Ali, Daru Wahyuni, Supriyanto, dan Endang Mulyani. (2009). Analisis Relevansi Lulusan Perguruan Tinggi dengan Dunia Kerja. Yogyakarta: Universitas Negeri Yogyakarta.

Peraturan Pemerintah Republik Indonesia Nomor 52 Tahun 2012 tentang Sertifikasi Kompetensi dan Sertifikasi Usaha di Bidang Pariwisata.

Prawirosentono, S. (2008). Manajemen Sumber Daya Manusia, Kebijakan Kinerja Karyawan. Yogyakarta: BPFE.

Rahman, Abdul. (2013). Pengaruh Karakteristik Individu, Motivasi dan Budaya Kerja terhadap Kinerja Pegawai pada Badan Keluarga Berencana dan Pemberdayaan Perempuan Kabupaten Donggala. (Tesis). Palu: Universitas Tadulako Palu.

Soeprihanto, Jhon. (2000). Penilaian Kinerja dan Pengembangan Karyawan. Yogyakarta: BPFE.

Toha, Miftah. (2003). Perilaku Organisasi Konsep Dasar dan Aplikasinya. Jakarta: Grafindo Persada. 
Journal of Indonesian Tourism, Hospitality and Recreation --- Volume 1, Nomor 2, Oktober 2018

Undang-Undang Republik Indonesia Nomor 10 Tahun 2009 tentang Kepariwisataan.
Winardi. (2004). Manajemen Perilaku Organisasi. Jakarta: Kencana Prenada Media Group. 